\title{
Maternal Loss of Ube3a Impairs Experience-Driven Dendritic Spine Maintenance in the Developing Visual Cortex
}

\author{
Hyojin Kim, ${ }^{1,2 \star}$ Portia A. Kunz, ${ }^{1,2,3 *}$ Richard Mooney, ${ }^{4}{ }^{-B e n j a m i n}$ D. Philpot, ${ }^{1,2,3}$ and $\mathbb{D}^{-S p e n c e r ~ L . ~ S m i t h ~}{ }^{1,2,3}$ \\ ${ }^{1}$ Department of Cell Biology and Physiology, ${ }^{2}$ Neuroscience Center, and ${ }^{3}$ Carolina Institute for Developmental Disabilities, University of North Carolina, \\ Chapel Hill, North Carolina 27599, and ${ }^{4}$ Department of Neurobiology, Duke University School of Medicine, Durham, North Carolina 27710
}

Dendritic spines are a morphological feature of the majority of excitatory synapses in the mammalian neocortex and are motile structures with shapes and lifetimes that change throughout development. Proper cortical development and function, including cortical contributions to learning and memory formation, require appropriate experience-dependent dendritic spine remodeling. Dendritic spine abnormalities have been reported for many neurodevelopmental disorders, including Angelman syndrome (AS), which is caused by the loss of the maternally inherited UBE3A allele (encoding ubiquitin protein ligase E3A). Prior studies revealed that UBE3A protein loss leads to reductions in dendritic spine density and diminished excitatory synaptic transmission. However, the decrease in spine density could come from either a reduction in spine formation or an increase in spine elimination. Here, we used acute and longitudinal in vivo two-photon microscopy to investigate developmental and experience-dependent changes in the numbers, dynamics, and morphology of layer 5 pyramidal neuron apical dendritic spines in the primary visual cortex of control and AS model mice $\left(U b e 3 a^{\mathrm{m}-/ \mathrm{p}^{+}}\right.$mice). We found that neurons in AS model mice undergo a greater elimination of dendritic spines than wild-type mice during the end of the first postnatal month. However, when raised in darkness, spine density and dynamics were indistinguishable between control and AS model mice, which indicates that decreased spine density in AS model mice reflects impaired experience-driven spine maintenance. Our data thus demonstrate an experience-dependent anatomical substrate by which the loss of UBE3A reduces dendritic spine density and disrupts cortical circuitry.

Key words: two-photon; Angelman syndrome; dendritic spine; E6AP; Ube3a; visual cortex

Significance Statement

Reduced dendritic spine densities are common in the neurodevelopmental disorder Angelman syndrome (AS). Because prior reports were based on postmortem tissue, it was unknown whether this anatomical deficit arises from decreased spine formation and/or increased spine elimination. Here, we used in vivo two-photon imaging to track spines over multiple days in a mouse model of AS. We found that spine formation is normal, but experience-dependent spine maintenance is reduced in the visual cortex of AS model mice. Our data pinpoint the anatomical process underlying the loss of dendritic spines, which can account for the decreased excitatory synaptic connectivity associated with AS. Therefore, normalizing spine maintenance is a potential therapeutic strategy.

\section{Introduction}

Angelman syndrome (AS) is a neurodevelopmental disorder caused by loss-of-function of the UBE3A protein (Kishino et al.,
1997). The UBE3A gene encodes a HECT (homologous to E6associated protein $\mathrm{C}$ terminus) domain E3 ubiquitin ligase. Neurons in the brain express the maternal, but not paternal, allele of 
UBE3A due to genetic imprinting (Kishino et al., 1997; Landers et al., 2004). Therefore, deletions or mutations of the maternal $U B E 3 A$ allele cause the complete loss of UBE3A protein in almost all central neurons (Kishino et al., 1997; Judson et al., 2014). AS phenotypes begin to present during early life $(\sim 1$ year $)$ and are characterized by severe cognitive impairments, seizures, minimal speech, hypermotoric behavior, and a short attention span (Clayton-Smith and Laan, 2003).

To help identify dendritic spine deficits contributing to the anatomical and cognitive impairments in AS, we took advantage of the visual cortex as a model system to explore the early sensitive periods during which experience can leave a lasting imprint on the brain (Hubel and Wiesel, 1970; Mower, 1991; Hensch, 2005; Levelt and Hübener, 2012). Such studies have served as a useful tool for identifying the synaptic mechanisms of learning and memory and for exposing synaptic deficits that underlie neurological disorders (Penzes et al., 2011; Cooke and Bear, 2014). These studies have shown, for example, that dendritic spines rapidly change in number and shape after various sensory and behavioral manipulations (Shepherd et al., 2003; Mataga et al., 2004; Hofer et al., 2009; Tropea et al., 2010; Miquelajauregui et al., 2015) and that changes in dendritic spine shape and/or density are common in neurodevelopmental disorders and their animal models (Nimchinsky et al., 2001; Hutsler and Zhang, 2010; Pan et al., 2010; Penzes et al., 2011; Till et al., 2012). Although appropriate changes in dendritic spines support normal learning, memory, and cognitive function, abnormal dendritic spine development may contribute to cortical dysfunction and associated behavioral abnormalities such as those observed in individuals with AS.

Reduced dendritic spine density has been one of the most consistent anatomical observations in both AS patients and AS model mice. In the only human postmortem anatomical AS study performed to date, dendritic spine density was shown to be reduced in layer 3 (L3) and L5 pyramidal neurons within the visual cortex (Jay et al., 1991). Consistent with those observations, AS model mice (Ube $3 a^{\mathrm{m}-/ \mathrm{p}^{+}}$mice) exhibit reduced dendritic spine density in L2/3 pyramidal neurons (Yashiro et al., 2009) and in basal dendrites of L5 pyramidal neurons (Sato and Stryker, 2010) in the visual cortex. These changes are correlated with reductions in excitatory synaptic transmission (Wallace et al., 2012), suggesting that reductions in dendritic spines and excitatory synaptic transmission are causally linked. Reduced spine density has also been observed on secondary apical dendrites of L3-L5 cortical pyramidal neurons in AS model mice (Dindot et al., 2008). The loss of UBE3A may cause generalized reductions in dendritic spine density given that AS model mice also exhibit reduced spine density in the cerebellum and hippocampus (Dindot et al., 2008).

Despite consistent observations of reduced dendritic spine density in an AS individual and in mouse models, how the loss of UBE3A affects the experience-driven formation and elimination of dendritic spines during development remains unclear. To resolve this issue, we used longitudinal two-photon microscopy in wild-type and AS model mice to examine dendritic spine turnover in L5 pyramidal neuron tufts, where changes in visual input are known to alter spine dynamics (Majewska et al., 2006; Tropea et al., 2010). We focused on spine maintenance across a critical period during which visual cortex connectivity is normally sensitive to experience-driven rearrangements, such as the ocular dominance plasticity that occurs as a consequence of brief monocular deprivation (Gordon and Stryker, 1996). Our studies revealed that AS model mice exhibit a larger proportion of thinner dendritic protrusions and reduced spine density, the latter of which resulted from impaired experience-dependent spine maintenance. Our findings indicate that maternal Ube3a plays an important role in the experience-dependent maturation of excitatory synapses in the visual cortex.

\section{Materials and Methods}

Animals. Mice carrying a Ube3a deletion were bred on a C57BL/6 background (Jiang et al., 1998). Ube $3 a^{\mathrm{m}+/ \mathrm{p}-}$ females were crossed with Thy1-GFP (line O) males (Feng et al., 2000) to obtain AS model mice $\left(U b e 3 a^{\mathrm{m}-/ \mathrm{p}^{+}}\right.$) and control mice $\left(U b e 3 a^{\mathrm{m}+/ \mathrm{p}+}\right.$ ) expressing GFP in $L 5$ pyramidal neurons. Male and female mice were used at different ages [postnatal day 14 (P14)-P38] and were raised either on a $12 \mathrm{~h}$ light/dark cycle (normally raised; NR) or in constant darkness (lightdeprived; LD) starting on the first day of surgery (between P24 and P31) for two-photon imaging. All animal procedures were performed in compliance with animal care guidelines at the University of North Carolina at Chapel Hill.

Cranial window surgery. Mice were anesthetized with ketamine $(80 \mathrm{mg} / \mathrm{kg})$ and xylazine $(6 \mathrm{mg} / \mathrm{kg})$ and administered ketorolac $(10 \mathrm{mg} /$ kg; Hospira) and cefazolin ( $22 \mathrm{mg} / \mathrm{kg}$; Sagent Pharmaceuticals) subcutaneously to reduce edema and local tissue inflammation. A head plate (inner diameter, $5 \mathrm{~mm}$; custom-made, stainless steel) was placed directly on the skull and secured with Vetbond ( $n$-butyl cyanoacrylate; $3 \mathrm{M})$. Mice were positioned in a head-plate holder (custom-made, stainless steel mounting apparatus) for craniotomy. A craniotomy (3-4 mm diameter) was made over the primary visual cortex and a $3 \mathrm{~mm}$ glass coverslip (\#1; Warner Instruments) was placed over the pial surface and secured to the skull with Vetbond. Dental acrylic (Ortho Jet; Lang Dental) was then applied across the skull surface and over the edges of the coverslip.

Two-photon imaging. Images were acquired on an upright Zeiss LSM $7 \mathrm{MP}$ and a Coherent Vision S titanium-sapphire laser was focused on the specimen by a W-Plan Apochromat $20 \times / 1.0$ numerical aperture objective. Fluorescence was collected by the same objective, filtered, and recorded by a GaAsP detector in a BiG module. Image acquisition and processing were controlled through the Zen software package. Dendritic segments of visual cortex were imaged at high resolution $(1024 \times 1024$ pixels, $0.21 \mu \mathrm{m} /$ pixel, $1 \mu \mathrm{m} z$-steps). In GFP-O mice, the vast majority of neurons expressing GFP are located in L5 (Feng et al., 2000; also see Fig. $1 b$ ) and, in most cases, the identity of L5 pyramidal neurons was confirmed using low-magnification image stacks collected from the cortical surface to the soma $(1024 \times 1024$ pixels, $0.59 \mu \mathrm{m} /$ pixel, $4 \mu \mathrm{m}$ $z$-steps). Therefore, we assumed that the dendritic segments we imaged and analyzed belonged to L5 pyramidal neurons. We acutely or chronically imaged apical tufts of L5 pyramidal neurons $(\sim 100 \mu \mathrm{m}$ below the cortical surface). Blood vessel patterns were used as initial references to guide chronic imaging of the same dendritic segments.

Chronic imaging took place over two imaging sessions; the first session occurred the day after the surgery and the second was performed $7 \mathrm{~d}$ after the surgery. Durotomy or bone growth removal was occasionally required for optical clarity the day before the second imaging session (Goldey et al., 2014). The chronic window surgery did not appear to cause abnormal microglial cell activation (Xu et al., 2007). The morphology and density of Iba1-labeled microglia were not different between the hemispheres ipsilateral and contralateral to the window (quantified the day after surgery; Iba1-positive cells $/ \mathrm{mm}^{2}$ in contralateral vs ipsilateral to surgery cortex $=476.0 \pm 31.39$ vs $475.3 \pm 21.67, p=0.979, n=3$, Student's paired $t$ test; Goldey et al., 2014).

Image analysis. Spine analyses were performed on 3D image stacks using ImageJ by an experimenter blinded to genotype and experimental manipulation. Three-dimensional image stacks were auto-aligned and smoothed using a Gaussian filter. Images exhibiting changes in fluorescence or rotational artifacts were excluded from further analysis. Spine density was measured in 60-138 $\mu \mathrm{m}$ dendritic segments and quantified by spine number divided by dendrite length. As a basis for comparison, a lower L5 spine density was calculated in wild-type mice at 4 weeks of age than measured in previous studies $[\sim 4$ spines $/ 10 \mu \mathrm{m}$ (Fig. $1 g$ ) vs $\sim 5.5-6$ spines/10 $\mu \mathrm{m}$, as seen in Majewska and Sur, 2003; Tropea et al., 2010]. This might have reflected strain or analysis differences, but, similar to 
a

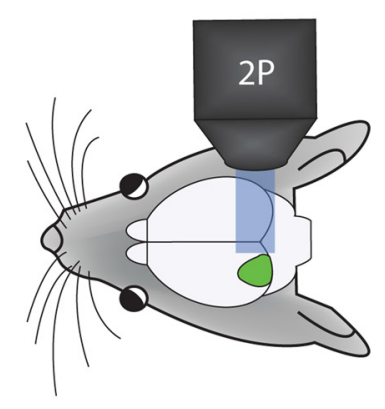

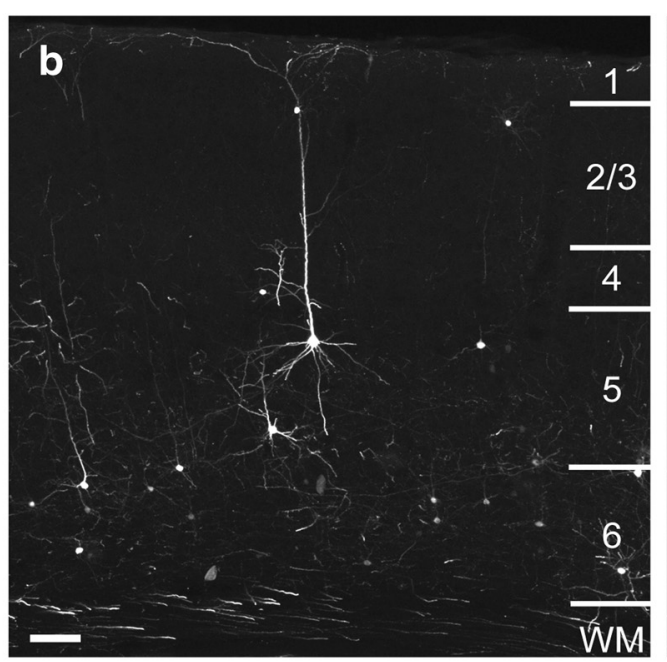

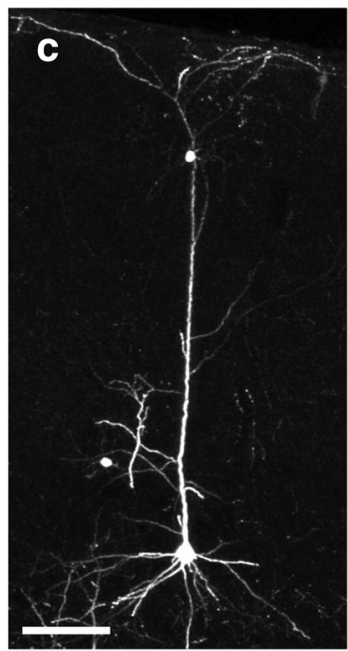

AS
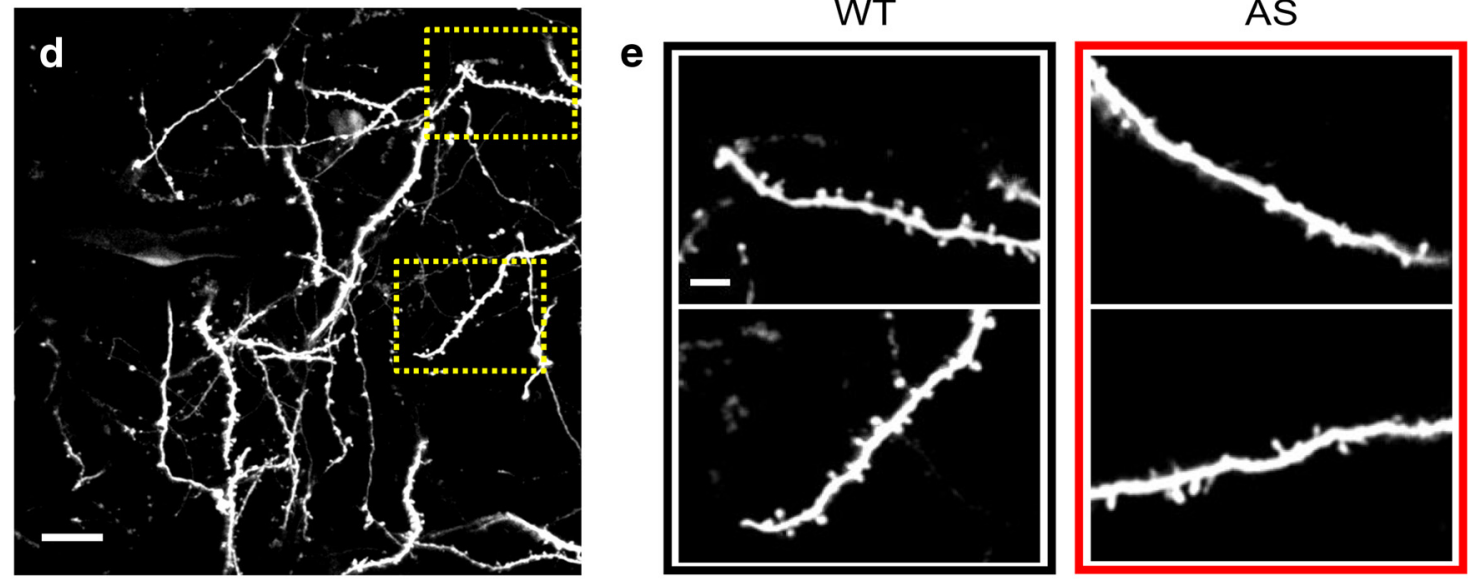

g

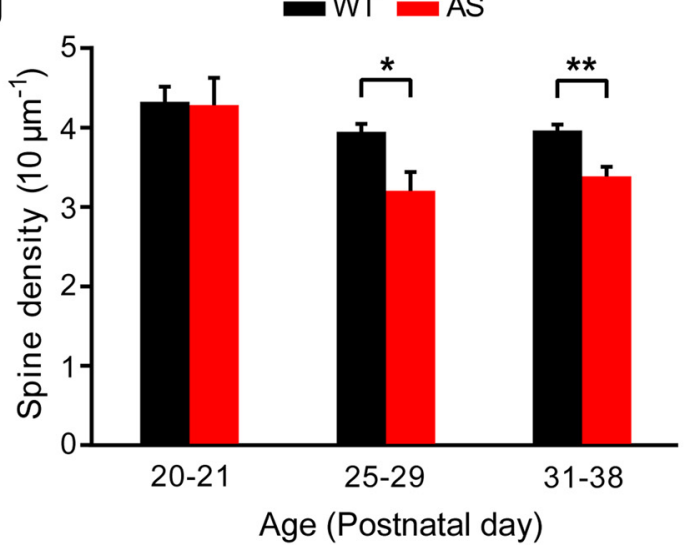

Figure 1. Developmental reduction in dendritic spine density in L5 visual cortical pyramidal neurons in AS model mice. $\boldsymbol{a}$, Schematic illustrating approach for two-photon (2P) in vivo imaging in mouse primary visual cortex. $\boldsymbol{b}$, Confocal image of representative L5 neurons from coronal sections of GFP-expressing mice (Thy1-GFP-0 mice). Laminar designations illustrate the location of GFP-expressing cells in visual cortex. Scale bar, $100 \mu \mathrm{m}$. $\boldsymbol{c}$, Higher-magnification view of imaged L5 neurons shown in $\boldsymbol{b}$. Scale bar, $100 \mu \mathrm{m}$. $\boldsymbol{d}$, Two-photon image of apical dendritic branches in the primary visual cortex from a P31 WT mouse. Scale bar, $50 \mu \mathrm{m} . \boldsymbol{e}$, Higher-magnification two-photon images of dendritic segments from WT mice (from boxed segments in $\boldsymbol{d}$ ) and AS mice. Scale bar, $5 \mu \mathrm{m} . \boldsymbol{f}$, Scatter plots of dendritic spine density from L 5 neurons in WT and AS mice during the sensory critical period (WT: 23 mice, 7267 spines, and AS: 21 mice, 5188 spines). $\boldsymbol{g}$, Average density of dendritic spines as a function of age in wild-type mice (P20-P24, $n=4$ mice, 1656 spines; P25-P29, $n=7$ mice, 1864 spines; P31-P38, $n=9$ mice, 2489 spines) and AS mice (P20 -P24, $n=$ 3 mice, 1295 spines; P25-P29, $n=7$ mice, 1194 spines; P31-P38, $n=10$ mice, 2731 spines). Student's unpaired $t$ test. ${ }^{*} p<0.05,{ }^{* *} p<0.01$. Error bars indicate SEM.

previous studies, we observed that spine density was relatively stable between P25 and P38 (see Fig. 1 fand Holtmaat et al., 2005; Hofer et al., 2009).

The rates of spine formation and elimination were defined, respectively, as the number of spines that appeared and disappeared relative to the total spine number of the previous imaging session. Spine subtypes (mushroom, stubby, and thin) were quantified using NeuronStudio (Rodriguez et al., 2008).

Immunohistochemistry. Mice were anesthetized with sodium pentobarbital ( $40 \mathrm{mg} / \mathrm{kg}$ ) before transcardial perfusion with PBS, immediately 
a

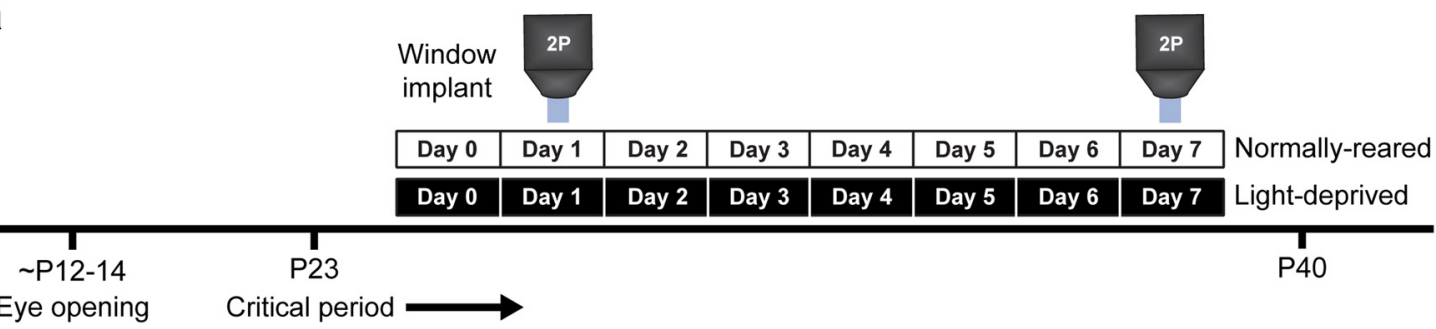

b

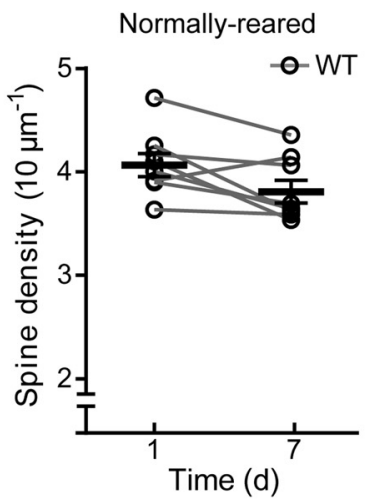

e

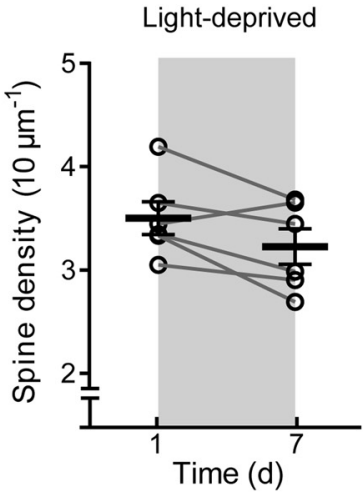

C

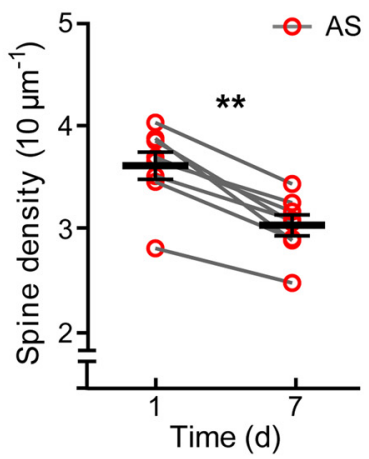

f

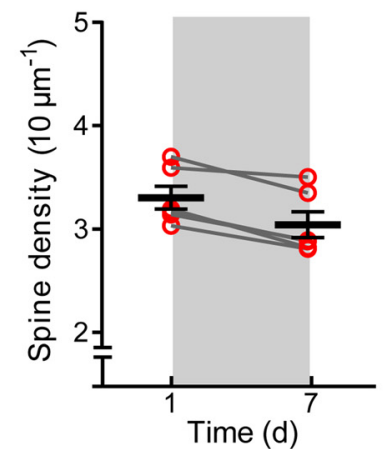

d

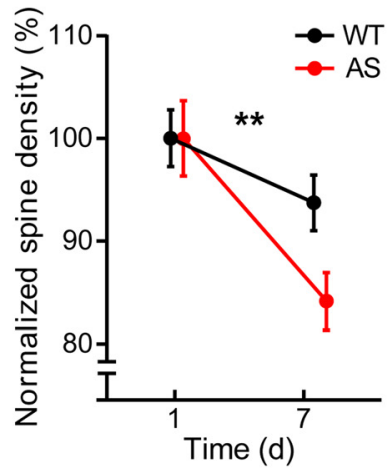

g

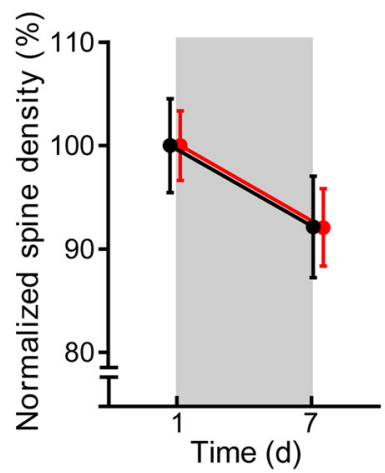

Figure 2. Light deprivation abrogates genotypic differences in dendritic spine density. $\boldsymbol{a}$, Schematic of experimental design. NR animals were maintained in a $12 \mathrm{~h}$ consecutive light-dark cycle and LD animals were housed in constant darkness immediately after surgery. $\boldsymbol{b}-\boldsymbol{d}$, Individual $(\boldsymbol{b}, \boldsymbol{c})$ and average normalized $(\boldsymbol{d})$ spine density changes across a $7 \mathrm{~d}$ interval in NR WT and AS mice ( $\boldsymbol{b}$ :WT, $n=8$ mice, 1453 spines; $\boldsymbol{c}$ : AS, $n=8$ mice, 1871 spines). $\boldsymbol{e}-\boldsymbol{g}$, Individual $(\boldsymbol{e}, \boldsymbol{f})$ and average normalized $(\boldsymbol{g})$ spine density changes across a 7 dinterval in light-deprived WT and AS mice $(\boldsymbol{e}$ : WT, $n=6$ mice, 1481 spines; $\boldsymbol{f}$ : AS, $n=6$ mice, 442 spines). For $\boldsymbol{b}, \boldsymbol{c}, \boldsymbol{e}$, and $\boldsymbol{f}$, Student's paired $t$ test was used; for $\boldsymbol{d}$ and $\boldsymbol{g}$, two-way ANOVA was used. ${ }^{* *} p<0.01$. Error bars indicate SEM.

followed by $4 \%$ paraformaldehyde in PBS, $\mathrm{pH}$ 7.4. Brains were postfixed overnight at $4^{\circ} \mathrm{C}$ before sequential $24 \mathrm{~h}$ incubations in PBS with $10 \%$, $20 \%$, and $30 \%$ sucrose. Brains were sectioned coronally at $40 \mu \mathrm{m}$ (for Ibal staining) or $100 \mu \mathrm{m}$ (for Thyl-GFP visualization) using a freezing sliding microtome (Thermo Scientific). Sections were stored at $4^{\circ} \mathrm{C}$ in a cryopreservative solution (45\% PBS, 30\% ethylene glycol, 25\% glycerol, by volume). For Iba1 immunostaining, sections were rinsed several times with PBS before blocking with 5\% normal goat serum and $0.02 \%$ Triton $\mathrm{X}-100$ in PBS for $1 \mathrm{~h}$ at room temperature. Sections were then incubated with primary antibody (Wako 019-19741, rabbit anti-Iba1, 1:600), diluted in normal goat serum at $4^{\circ} \mathrm{C}$ overnight, and then rinsed several times with $0.02 \%$ Triton X-100 in PBS. Tissues were then incubated with secondary antibody (Life Technologies, Alexa Fluor-568 goat anti-rabbit IgG A11011, 1:500) for $2 \mathrm{~h}$. Images were acquired with a Zeiss LSM 780 confocal microscope.

Statistics. Graphs were generated and statistical analyses were performed using GraphPad Prism 6 software. Data are represented as the mean \pm SEM unless otherwise indicated. For statistical analyses, twotailed Student's paired and unpaired $t$ tests and two-way ANOVA were used as indicated. Statistical significance is represented as follows: ${ }^{*} p<$ $0.05,{ }^{* *} p<0.01$, and ${ }^{* * * *} p<0.0001$.

\section{Results}

Decreases in spine density are greater in L5 pyramidal neuron apical tufts in AS model mice

We imaged dendritic spines on apical tufts of L5 pyramidal neurons using in vivo two-photon microscopy acutely between P14 and P38 during visual cortex development (Fig. 1a-e). Although spine density appeared similar between WT and AS mice early in development $(<\mathrm{P} 21)$, spine density at older ages was lower in AS mice than in WT controls (Fig. $1 f$ ). We quantified spine density by dividing the data into three age groups (P20-P21, P25-P29, and $\mathrm{P} 31-\mathrm{P} 38$ ) and verified that dendritic spine density decreased in AS mice during the latter part of the critical period (P25-P29: $3.93 \pm 0.09$ vs $3.19 \pm 0.23$ spines $/ 10 \mu \mathrm{m}, p<0.013$, unpaired $t$ test; P31-P38: $3.95 \pm 0.07$ vs $3.37 \pm 0.12$ spines $/ 10 \mu \mathrm{m}, p<$ 0.001 , unpaired $t$ test; Fig. $1 g$ ). These data indicate that, although apical dendrites of L5 pyramidal neurons in AS mice exhibit normal spine density during early postnatal development, reduced dendritic spine density emerges after the third postnatal week. 
Chronic imaging reveals a role for UBE3A in regulating dendritic spine density

Using longitudinal imaging through a chronic cranial window (Holtmaat et al., 2009), we tested whether visual experience differentially modified dendritic spine dynamics in the absence of maternal Ube3a. We focused on developmental changes after P25, when we observed differences in spine density between the genotypes in our acute imaging experiments (Fig. $1 g$ ). We imaged spines on the apical dendritic tufts of individual L5 neurons across a $7 \mathrm{~d}$ interval in NR mice (12:12 h light-dark cycle) and LD mice ( $24 \mathrm{~h}$ darkness; Fig. 2a). Spine density did not change significantly and trended downward across imaging sessions in WT mice ( $p=0.055$, paired $t$ test; Fig. $2 b$ ), but was significantly reduced over this same interval in AS model mice ( $p=0.007$, paired $t$ test; Fig. $2 c)$. A two-way ANOVA revealed a significant effect of genotype $\left(F_{(1,28)}=\right.$ $10.2, p=0.003)$, time $\left(F_{(1,28)}=53, p<\right.$ $0.0001)$, and a genotype-time interaction $\left(F_{(1,28)}=10.2, p=0.003\right.$; Fig. $\left.2 d\right)$. However, the same chronic imaging approach in LD mice failed to reveal differences by genotype $\left(F_{(1,20)}=0.004, p=0.953\right)$, but did suggest that there was a modest but significant effect of time on spine density $\left(F_{(1,20)}=18.10, p=0.0004\right.$; Fig. $\left.2 e-g\right)$. These results indicate that visual experience drives an abnormal reduction in dendritic spine density in AS model mice and light deprivation prevents this genotypic difference.

\section{AS model mice have impaired experience-driven dendritic spine maintenance}

In visual cortical development, sensory experience influences dendritic spine turnover, which is determined by the relative rates of spine formation and elimination (Holtmaat et al., 2009). In many brain regions, synapse formation declines whereas synapse elimination increases during development, resulting in a net decrease of dendritic spines before the stabilization of spine density (Zuo et al., 2005; Yang et al., 2009). In AS model mice, we observed reduced dendritic spine density during later stages of the critical period for ocular dominance plasticity, but it is unknown whether this net spine loss is due to changes in the rates of spine elimination or formation. To determine how UBE3A regulates experience-dependent spine dynamics, we quantified spine formation and elimination over a $7 \mathrm{~d}$ window in NR and LD conditions (Fig. 3a). The rates of spine formation were similar across this $7 \mathrm{~d}$ window in WT and AS mice and the rates were not affected by visual experience (NR: WT vs AS $=14.82 \pm 1.79 \%$ vs $16.43 \pm 0.98 \%, p=0.443 ; \mathrm{LD}: \mathrm{WT}$ vs AS $=14.69 \pm 1.61 \%$ vs $13.48 \pm 0.55 \%, p=0.490$; 2 -way ANOVA; Fig. $3 b$ ). However, under normal rearing conditions, AS mice exhibited greater dendritic spine elimination across a $7 \mathrm{~d}$ period than WT mice (NR: WT vs AS $=22.73 \pm 1.12 \%$ vs $30.23 \pm 2.14 \%$, $p=0.008$; 2 -way ANOVA; Fig. $3 c$ ). However, light deprivation eliminated the genotype differences (LD: WT vs AS $=23.09 \pm$ $1.09 \%$ vs $24.05 \pm 0.95 \%, p=0.525 ; 2$-way ANOVA; Fig. $3 c$ ). These results indicated that the presence of UBE3A helps to limit spine elimination in response to visual experience.

Prior studies have shown that larger spines, such as mushroom and stubby spines, are more persistent than smaller spines, which tend to have shorter lifetimes (Kasai et al., 2003; Holtmaat et al., 2005). An increase in the spine elimination rate observed in AS mice raised the possibility of an abundance of spines with immature morphology. To address this issue, we categorized spines into three morphologies (mushroom, stubby, and thin; Fig. 4a). Although we observed no effect of genotype or visual experience on the proportion of mushroom spines, we did find a much higher proportion of thin spines and a lower proportion of stubby spines in AS mice than in WT mice (thin: WT vs AS = $17.91 \pm 0.53 \%$ vs $31.07 \pm 0.85 \%, p<0.0001$; stubby: WT vs AS $=38.53 \pm 2.25 \%$ vs $29.75 \pm 1.11 \%, p=0.004 ; 2$-way ANOVA; Fig. 4b). However, the genotype-dependent changes in spine types were no longer observed in light-deprived mice (thin: WT vs AS $=20.17 \pm 0.87 \%$ vs $21.07 \pm 1.32 \%, p=0.604$; stubby: WT vs AS $=36.45 \pm 0.77 \%$ vs $36.19 \pm 1.44 \%, p=0.878 ; 2$-way ANOVA; Fig. 4b). Together, our data demonstrate that UBE3A supports the experience-dependent maintenance of mature spines during visual cortex development. 
a
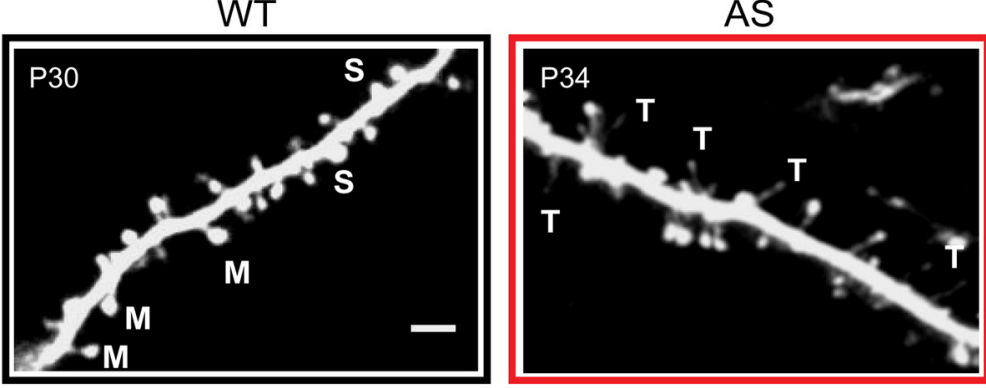

b
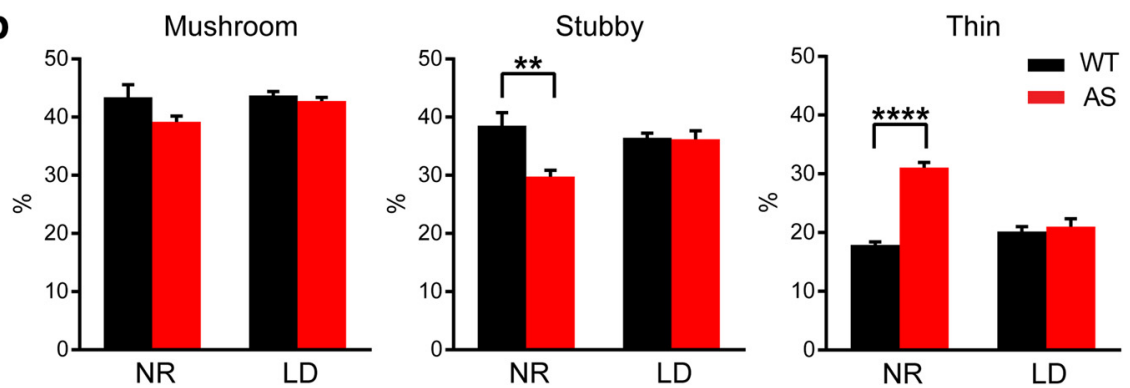

Figure 4. AS mice exhibit more thin, filopodia-like dendritic spines than WT mice. $\boldsymbol{a}$, Representative classification of dendritic spines in a NR WT and AS mouse. M, Mushroom; S, stubby; T, thin. Scale bar, $5 \mu \mathrm{m}$. $\boldsymbol{b}$, Percentage of mushroom spines (rearing condition: $F_{(1,16)}=2.37, p=0.143$; genotype: $F_{(1,16)}=4.10, p=0.060$; interaction: $\left.F_{(1,16)}=1.67, p=0.214\right)$, stubby spines (rearing condition: $F_{(1,16)}=2.13, p=0.164$; genotype: $F_{(1,16)}=9.12, p=0.008$; interaction: $\left.F_{(1,16)}=8.11, p=0.012\right)$, and thin spines (rearing condition: $F_{(1,16)}=17.30, p=0.0007$; genotype: $F_{(1,16)}=56.11, p<0.0001$; interaction: $F_{(1,16)}=43.24$, $p<0.0001$ ) in WT (NR: $n=5$ mice, 2655 spines; LD: $n=5$ mice, 2015 spines) and AS mice (NR: $n=5$ mice, 3580 spines; LD: $n=$ 5 mice, 1509 spines). ${ }^{* *} p<0.01,{ }^{* * * *} p<0.0001$, two-way ANOVA with Sídák's multiple comparisons. Error bars indicate SEM.

\section{Discussion}

We used longitudinal in vivo imaging to reveal the abnormal dendritic spine dynamics that underlie the reduced spine densities observed in AS model mice (Yashiro et al., 2009; Sato and Stryker, 2010) and, by extension, in individuals with AS (Jay et al., 1991). Our data demonstrate that, in the apical tufts of L5 pyramidal neurons in the visual cortex, maternal loss of Ube3a impairs the experiencedriven maintenance of dendritic spines during an important developmental sensitive period. We also observed a greater fraction of thin spines compared with mushroom or stubby spines in AS model mice, indicating that the loss of UBE3A disrupts spine maturation. Thin spines are generally immature, highly dynamic, and have shorter lifetimes compared with other spine types (Holtmaat et al., 2005). Therefore, these thin spines could be particularly susceptible to experience-driven spine elimination. This is consistent with our observation that, when AS model mice and control mice are light deprived, spine elimination rates are not different between the two groups. Our data thus support a model in which UBE3A promotes synapse stabilization during cortical circuit development.

Here, we demonstrated a role for UBE3A in the experiencedependent maintenance of dendritic spine density in L5 pyramidal neurons (Fig. 2). Our results are similar to a Golgi-method study showing that the loss of UBE3A also reduces spine density in L2/3 pyramidal neurons (Yashiro et al., 2009). Therefore, both $\mathrm{L} 2 / 3$ and L5 pyramidal neurons require UBE3A for normal spine development and maintenance in the visual cortex, a process that sensory experience strongly influences (Hofer et al., 2009; Tropea et al., 2010). Given that reduced dendritic spine densities have also been observed in the hippocampus and cerebellum of AS mice (Dindot et al., 2008), it is tempting to speculate that spine deficits in these circuits might also arise from inappropriate experience-driven sculpting of excitatory synapses. Such a possi- bility is consistent with the observations that the loss of UBE3A impairs excitatory synaptic plasticity in both the visual cortex (Yashiro et al., 2009) and hippocampus (Jiang et al., 1998) and that synaptic plasticity critically regulates the shape, size, and number of dendritic spines (Kasai et al., 2003; Spruston, 2008). Therefore, UBE3A likely plays a critical role in experience-dependent sculpting of dendritic spines in many brain regions.

The appropriate experience-driven addition or elimination of dendritic spines during sensory experience provides a physical basis for learning and memory (Hofer et al., 2009; Caroni et al., 2012; Hayashi-Takagi et al., 2015). Defects in the stabilization of dendritic spines, which are the major recipients of excitatory synaptic inputs in the brain, likely underlie reduced glutamatergic transmission from the loss of UBE3A (Wallace et al., 2012) and may contribute to the intellectual disability seen in individuals with AS. Our finding that maternal loss of Ube3a impairs experience-dependent dendritic spine plasticity, which is critical for circuit wiring during development, suggests a target for pharmacological interventions. Indeed, Ephexin5, a putative substrate of UBE3A-mediated degradation, regulates excitatory synapse development (Margolis et al., 2010). Therefore, this and other relevant UBE3A substrates are viable targets for correcting dendritic architecture as a treatment for AS.

\section{References}

Caroni P, Donato F, Muller D (2012) Structural plasticity upon learning: regulation and functions. Nat Rev Neurosci 13:478-490. CrossRef Medline

Clayton-Smith J, Laan L (2003) Angelman syndrome: a review of the clinical and genetic aspects. J Med Genet 40:87-95. CrossRef Medline

Cooke SF, Bear MF (2014) How the mechanisms of long-term synaptic potentiation and depression serve experience-dependent plasticity in primary visual cortex. Philos Trans R Soc Lond B Biol Sci 369:20130284. CrossRef Medline

Dindot SV, Antalffy BA, Bhattacharjee MB, Beaudet AL (2008) The Angelman syndrome ubiquitin ligase localizes to the synapse and nucleus, and maternal deficiency results in abnormal dendritic spine morphology. Hum Mol Genet 17:111-118. Medline

Feng G, Mellor RH, Bernstein M, Keller-Peck C, Nguyen QT, Wallace M, Nerbonne JM, Lichtman JW, Sanes JR (2000) Imaging neuronal subsets in transgenic mice expressing multiple spectral variants of GFP. Neuron 28:41-51. CrossRef Medline

Goldey GJ, Roumis DK, Glickfeld LL, Kerlin AM, Reid RC, Bonin V, Schafer DP, Andermann ML (2014) Removable cranial windows for long-term imaging in awake mice. Nat Protoc 9:2515-2538. CrossRef Medline

Gordon JA, Stryker MP (1996) Experience-dependent plasticity of binocular responses in the primary visual cortex of the mouse. J Neurosci 16: 3274-3286. Medline

Hayashi-Takagi A, Yagishita S, Nakamura M, Shirai F, Wu YI, Loshbaugh AL, Kuhlman B, Hahn KM, Kasai H (2015) Labelling and optical erasure of synaptic memory traces in the motor cortex. Nature 525:333-338. CrossRef Medline

Hensch TK (2005) Critical period plasticity in local cortical circuits. Nat Rev Neurosci 6:877-888. Medline

Hofer SB, Mrsic-Flogel TD, Bonhoeffer T, Hübener M (2009) Experience 
leaves a lasting structural trace in cortical circuits. Nature 457:313-317. CrossRef Medline

Holtmaat AJ, Trachtenberg JT, Wilbrecht L, Shepherd GM, Zhang X, Knott GW, Svoboda K (2005) Transient and persistent dendritic spines in the neocortex in vivo. Neuron 45:279-291. CrossRef Medline

Holtmaat A, Bonhoeffer T, Chow DK, Chuckowree J, De Paola V, Hofer SB, Hübener M, Keck T, Knott G, Lee WC, Mostany R, Mrsic-Flogel TD, Nedivi E, Portera-Cailliau C, Svoboda K, Trachtenberg JT, Wilbrecht L (2009) Long-term, high-resolution imaging in the mouse neocortex through a chronic cranial window. Nat Protoc 4:1128-1144. CrossRef Medline

Hubel DH, Wiesel TN (1970) The period of susceptibility to the physiological effects of unilateral eye closure in kittens. J Physiol 206:419-436. CrossRef Medline

Hutsler JJ, Zhang H (2010) Increased dendritic spine densities on cortical projection neurons in autism spectrum disorders. Brain Res 1309:83-94. CrossRef Medline

Jay V, Becker LE, Chan FW, Perry TL Sr (1991) Puppet-like syndrome of Angelman: a pathologic and neurochemical study. Neurology 41:416422. CrossRef Medline

Jiang YH, Armstrong D, Albrecht U, Atkins CM, Noebels JL, Eichele G, Sweatt JD, Beaudet AL (1998) Mutation of the Angelman ubiquitin ligase in mice causes increased cytoplasmic p53 and deficits of contextual learning and long-term potentiation. Neuron 21:799-811. CrossRef Medline

Judson MC, Sosa-Pagan JO, Del Cid WA, Han JE, Philpot BD (2014) Allelic specificity of Ube3a expression in the mouse brain during postnatal development. J Comp Neurol 522:1874-1896. CrossRef Medline

Kasai H, Matsuzaki M, Noguchi J, Yasumatsu N, Nakahara H (2003) Structure-stability-function relationships of dendritic spines. Trends Neurosci 26:360-368. CrossRef Medline

Kishino T, Lalande M, Wagstaff J (1997) UBE3A/E6-AP mutations cause Angelman syndrome. Nat Genet 15:70-73. CrossRef Medline

Landers M, Bancescu DL, Le Meur E, Rougeulle C, Glatt-Deeley H, Brannan C, Muscatelli F, Lalande M (2004) Regulation of the large (approximately $1000 \mathrm{~kb}$ ) imprinted murine Ube3a antisense transcript by alternative exons upstream of Snurf/Snrpn. Nucl Acids Res 32:3480-3492. CrossRef Medline

Levelt CN, Hübener M (2012) Critical-period plasticity in the visual cortex. Annu Rev Neurosci 35:309-330. CrossRef Medline

Majewska A, Sur M (2003) Motility of dendritic spines in visual cortex in vivo: changes during the critical period and effects of visual deprivation. Proc Natl Acad Sci U S A 100:16024-16029. CrossRef Medline

Majewska AK, Newton JR, Sur M (2006) Remodeling of synaptic structure in sensory cortical areas in vivo. J Neurosci 26:3021-3029. CrossRef Medline

Margolis SS, Salogiannis J, Lipton DM, Mandel-Brehm C, Wills ZP, Mardinly AR, Hu L, Greer PL, Bikoff JB, Ho HY, Soskis MJ, Sahin M, Greenberg ME (2010) EphB-mediated degradation of the RhoA GEF Ephexin5 relieves a developmental brake on excitatory synapse formation. Cell 143:442-455. CrossRef Medline

Mataga N, Mizuguchi Y, Hensch TK (2004) Experience-dependent pruning of dendritic spines in visual cortex by tissue plasminogen activator. Neuron 44:1031-1041. CrossRef Medline
Miquelajauregui A, Kribakaran S, Mostany R, Badaloni A, Consalez GG, Portera-Cailliau C (2015) Layer 4 pyramidal neurons exhibit robust dendritic spine plasticity in vivo after input deprivation. J Neurosci 35: 7287-7294. CrossRef Medline

Mower GD (1991) The effect of dark rearing on the time course of the critical period in cat visual cortex. Brain Res Dev Brain Res 58:151-158. CrossRef Medline

Nimchinsky EA, Oberlander AM, Svoboda K (2001) Abnormal development of dendritic spines in FMR1 knock-out mice. J Neurosci 21:5139_ 5146. Medline

Pan F, Aldridge GM, Greenough WT, Gan WB (2010) Dendritic spine instability and insensitivity to modulation by sensory experience in a mouse model of fragile X syndrome. Proc Natl Acad Sci U S A 107:17768-17773. CrossRef Medline

Penzes P, Cahill ME, Jones KA, VanLeeuwen JE, Woolfrey KM (2011) Dendritic spine pathology in neuropsychiatric disorders. Nat Neurosci 14: 285-293. CrossRef Medline

Rodriguez A, Ehlenberger DB, Dickstein DL, Hof PR, Wearne SL (2008) Automated three-dimensional detection and shape classification of dendritic spines from fluorescence microscopy images. PLoS One 3:e1997. CrossRef Medline

Sato M, Stryker MP (2010) Genomic imprinting of experience-dependent cortical plasticity by the ubiquitin ligase gene Ube3a. Proc Natl Acad Sci U S A 107:5611-5616. CrossRef Medline

Shepherd GM, Pologruto TA, Svoboda K (2003) Circuit analysis of experience-dependent plasticity in the developing rat barrel cortex. Neuron 38:277-289. CrossRef Medline

Spruston N (2008) Pyramidal neurons: dendritic structure and synaptic integration. Nat Rev Neurosci 9:206-221. CrossRef Medline

Till SM, Wijetunge LS, Seidel VG, Harlow E, Wright AK, Bagni C, Contractor A, Gillingwater TH, Kind PC (2012) Altered maturation of the primary somatosensory cortex in a mouse model of fragile X syndrome. Hum Mol Genet 21:2143-2156. CrossRef Medline

Tropea D, Majewska AK, Garcia R, Sur M (2010) Structural dynamics of synapses in vivo correlate with functional changes during experiencedependent plasticity in visual cortex. J Neurosci 30:11086-11095. CrossRef Medline

Wallace ML, Burette AC, Weinberg RJ, Philpot BD (2012) Maternal loss of Ube3a produces an excitatory/inhibitory imbalance through neuron type-specific synaptic defects. Neuron 74:793-800. CrossRef Medline

Xu HT, Pan F, Yang G, Gan WB (2007) Choice of cranial window type for in vivo imaging affects dendritic spine turnover in the cortex. Nat Neurosci 10:549-551. CrossRef Medline

Yang G, Pan F, Gan WB (2009) Stably maintained dendritic spines are associated with lifelong memories. Nature 462:920-924. CrossRef Medline

Yashiro K, Riday TT, Condon KH, Roberts AC, Bernardo DR, Prakash R, Weinberg RJ, Ehlers MD, Philpot BD (2009) Ube3a is required for experience-dependent maturation of the neocortex. Nat Neurosci 12: 777-783. CrossRef Medline

Zuo Y, Yang G, Kwon E, Gan WB (2005) Long-term sensory deprivation prevents dendritic spine loss in primary somatosensory cortex. Nature 436:261-265. CrossRef Medline 